\title{
Public and Private Partnership and Business Actors in Political Processes Concerning Military Issues
}

\author{
Submitted 15/08/19, 1st revision 20/09/19, 2nd revision 25/10/19, accepted 24/11/19
}

\author{
Martynenko El.V. ${ }^{1}$, Pepelov S.T. ${ }^{2}$
}

\begin{abstract}
:
Purpose: The article researches the actual issues of developing partnership and cooperation between the state and private business in matters of production and modernization the military-industrial complex of Russia. The main object of the research is the Russian NAVY. The subject of the research is the comparison of the Russian and US NAVY modernization in the context of public and private partnership.

Design/Methodology/Approach: The authors used a wide range of methodological tools in the course of the study. The method of economic analysis, the method of structural analysis, the statistical method and the method of mathematical comparison were used.

Findings. Studying the role of business actors in the national rearmament programmes in Russia the authors revealed such key indicators as economic viability and financial efficiency of programme implementation. A comparative analysis of budget and private funding of the similar US programme was conducted and statistical data supporting the main findings of the study were introduced.

Practical Implications: The development of cooperation between business and the MIC at the state level should go along the path of creating conditions for public-private partnerships (PPPs) - a set of organizational, legal, financial and economic relations and joint actions of the state and private business aimed at achieving the goals of the state economic policy in order to address socially significant tasks on mutually beneficial conditions.

Originality/Value: The authors' conclusion that state's financial and economic policy in the field of defense and modernization of the domestic defense industry has all chances to become the locomotive of the country's industrial, scientific and technological development gives new horizons for discussing the most appropriate rearmament strategy.
\end{abstract}

Keywords: Public and private partnership (PPP), financial policy, investment, risk, strategy, economic efficiency, military and industrial complex (MIC), NAVY.

JEL Code: C12, C67, E39, G28, H11.

Paper type: Research article: Public and Private Partnerships (PPP).

\footnotetext{
${ }^{1}$ Doctor of Science (Politics), Professor, Head of Theory and History of Journalism Department, RUDN University, martynenko-ev@rudn.ru

${ }^{2}$ Postgraduate, Political Analysis and Administration Department, RUDN University, scharnchorst@mail.ru
} 


\section{Introduction}

The relevance of the topic is determined by several factors. Firstly - the global processes in the sphere of industry. Over the past few years, significant institutional changes have occured in the world industries that previously generally referred to state property and state administration: electric power, road, rail, and municipal services, trunk pipeline transport, ports, airports, etc. Governments transfer objects of these industries for temporary long- and medium-term business use, while retaining the right to regulate and control their activities.

Secondly - modern realities in the development of the military and industrial complex (hereinafter MIC) in Russia pose such tasks, which require new or adaptation of existing financial, economic and organizational mechanisms. Among the most important tasks are the prompt import substitution of technologies that were still supplied from abroad; the development of new ones, as well as the modernization of existing weapons and military equipment, both in order to increase the country's defense capability, and in order to implement agreements in the framework of military-technical cooperation.

Not just the tasks, but also the conditions for the development of the MIC are substantially changing. The sluggish growth of the global economy and the implementation of Western sanctions against Russia hinder the growth of GDP and budget revenues. Control over the use of budget funds is being tightened. At the same time, since private companies occupy the dominant positions in industry, as well as in the economy as a whole, it becomes possible and expedient in certain cases to use extrabudgetary financing and public-private partnership mechanisms (hereinafter PPP) for the implementation of defense industry projects. Moreover, the simplification of the process of creating new production facilities in the defense industry, including through the use of PPP mechanisms, is one of the important areas of the Russian Government activities, which should be realized in accordance with Presidential Decree of May 7, 2012 No. 603 "On the implementation of plans construction and development of the Armed Forces of the Russian Federation, other troops, military units and bodies and modernization of the military-industrial complex." With the proper choice of a PPP model, the correct organization of the project and qualified expert support while using these mechanisms will allow to share financial and technological risks, to combine the strengths and competencies of partners on a long-term basis.

There is still little experience in implementing PPP projects in Russia, although quite a solid regulatory framework has already been outworked in the civilian sectors of economy. Sufficient for the use of public-private partnership mechanisms is the legal regulation of the status of public entities as participants in PPPs, as well as the regulation of contractual forms of PPPs. It is done a lot in the development of the regulatory framework related to intellectual property management. In 2017 in first reading of the State Dume the draft federal law on the Foundations of Public-Private 
Partnerships in the Russian Federation was adopted. A large set of concession regulations has been developed for various sectors of the economy (with the exception of the defense industry).

The authors of the article suppose, the country has basically already developed the conditions for the use of PPP mechanisms previously tested in other sectors of the economy in some specific projects of the military-industrial complex. And this can be done without waiting until the law "On Public-Private Partnership in the Field of Military-Technical Support of the Defense and National Security" has finally passed all the necessary stages of approval in the Federal Duma. It seems that the implementation of projects in the defense industry is possible with minor changes and additions to the existing regulatory framework for PPP.

\section{Russian Public and Private Sector as a Component of National Rearmament Program}

Currently, the cooperation between the defense industry and private business in Russia is mainly implemented in two ways - in the form of a state contract and privatization. This is obviously not enough. There are a number of constraints to its expansion, the main of which are economic ones (Samarin, 2014).

Today, the average profitability of enterprises of the Russian defense industry is lower than its level in industry as a whole. Therefore, the economic interest of private business in cooperation with the state in the defense industry is still small. The organization of effective interaction between the Russian defense industry complex (MIC) and private business is currently an extremely important task. Its relevance is due not only to the need to create a well-equipped Armed Forces that fully meets modern global challenges, but also to the need to restore the rhythmic and dynamic functioning of one of the most important sectors of the Russian economy, which in previous decades actually became a hostage to market reforms.

In August 2012, the President of the Russian Federation V.V. Putin identified one of the most important conditions for development of the MIC to improve the mechanisms of public-private partnership. For this, a Council at the Military Industrial Commission was created. It included more than 100 business representatives, as well as government agencies. Their work is built and divided into 10 groups by directions. To date, detailed Council work programs for each of the groups have been adopted. The concept of applying public-private partnership mechanisms in the military-industrial complex has already been approved. The purpose of its development was to determine the direction and ways of providing in the long run until 2020. the use of public-private partnerships in the militaryindustrial complex in the interests of creating and producing a new generation of weapons, military and special equipment (Glybin, 2014). 
The main focus is supposed to be on the development of a new modern regulatory framework governing the main directions of the application of public-private partnership mechanisms in the MIC, in particular, the extension of the scope of the draft Federal Law "On Public-Private Partnership in the Russian Federation". The government approved the draft of this law; it is currently under consideration by the State Duma. As many experts believe, without this it is not possible to effectively attract private investment.

Another area is an analysis of the regulatory and control and oversight functions of state authorities in relation to developers and manufacturers of defense industry products. Also - stimulation the availability of information in its open part, especially in the format of open data, about the needs of the military-industrial complex for new products and state order for the long term. The Ministry of Defense and the Military-Industrial Commission are conducting serious work in this direction (Vorushilin et al., 2014)

And, finally, ensuring proper monitoring the effectiveness of spending on the implementation of the state defense order. The Council adopted the concept of the PPP mechanisms application in the MIC, which was developed jointly with the Ministry of Industry and Trade, approved by the members of the Council, and will be built on the basis of practical application of this concept. Work is underway on a draft procedure for the creation of weapons and special equipment at the expense of organizations and investors of the private sector on an initiative basis. At the moment, the corresponding regulation does not exist, therefore, initiative developments, in essence, remained outside the legal field.

According to experts, the main problems of public-private partnership in the military-industrial complex are: licensing (it takes a lot of time and resources); access for R\&D use by companies with private capital; the ability to access the training grounds for testing new equipment. Also the need for the availability of capital for the creation of new industries is noted, the guarantee of a state order, which should be valid for more than 10 years, and the resolution of the issue of intellectual property rights and development are bieng criticized (Shishkov, 2015).

The main tasks that the Council sets for itself at the military-industrial commission are the following: to improve the regulatory framework and to develop cooperation and attraction of private companies at the second level of cooperation - at the level of sub-contracts. This could be a serious tool to reduce costs. Maximizing direct support to pilot projects for the creation and production of new prototypes that are produced with the participation of private capital. And there are already some successful examples. In particular, the experience in creating armored vehicles by the Basel group, the new small arms - ORSIS and Strizh.

According to V.G. Varnavsky (2010), the following main forms of PPP are used in the Russian Federation: 
- government contracts with investment obligations;

- participation in capital;

- concession agreements (concessions);

- production sharing agreements;

- contracts combining various types of work and property relations.

Involvement of inefficiently used lands in the economic turnover may also give additional turn to the MIC development. The defense industry is the largest land holder throughout the country. However, these land resources are not fully used for their own needs, and some of them are potentially attractive for business development. In addition, legislative restrictions do not allow using them not only for civilian needs, but also for organizing the production of the defense industry.

Table 1. The most promising spheres of PPP in the field of defense and security ${ }^{3}$

\begin{tabular}{|c|c|c|c|}
\hline $\begin{array}{l}\text { Directions/ } \\
\text { forms }\end{array}$ & $\begin{array}{l}\text { Military } \\
\text { Infrastructure }\end{array}$ & $\begin{array}{l}\text { «Fighter } \\
\text { Infrastructure» }\end{array}$ & $\begin{array}{l}\text { Military and } \\
\text { technical support }\end{array}$ \\
\hline $\begin{array}{l}\text { Life cycle } \\
\text { contracts }\end{array}$ & $\begin{array}{l}\text { - construction and using } \\
\text { of objects and structures } \\
\text { for the Ministry of } \\
\text { Defense } \\
\text { - Creation / } \\
\text { modernization with } \\
\text { subsequent operation of } \\
\text { communication } \\
\text { facilities and troops } \\
\text { management. }\end{array}$ & $\begin{array}{l}\text { construction and } \\
\text { using of objects } \\
\text { and structures in } \\
\text { the interests of the } \\
\text { Ministry of } \\
\text { Defense }\end{array}$ & $\begin{array}{l}\text { - introduction of new } \\
\text { technologies and } \\
\text { projects } \\
\text { - mass production } \\
\text { and maintenance } \\
\text { (with disposal) } \\
\text { BBCT } \\
\text { - modernization and } \\
\text { maintenance BBCT }\end{array}$ \\
\hline $\begin{array}{l}\text { Concession } \\
\text { agreements }\end{array}$ & $\begin{array}{l}\text { construction and using } \\
\text { of objects and structures } \\
\text { in the interests of the } \\
\text { Ministry of Defense }\end{array}$ & $\begin{array}{l}\text { construction and } \\
\text { using of objects } \\
\text { and structures in } \\
\text { the interests of the } \\
\text { Ministry of } \\
\text { Defense }\end{array}$ & $\begin{array}{l}\text { organization of mass } \\
\text { production and } \\
\text { service BBCT }\end{array}$ \\
\hline $\begin{array}{l}\text { Joint } \\
\text { industries } \\
\text { ("project } \\
\text { companies") }\end{array}$ & $\begin{array}{l}\text { creation of enterprises } \\
\text { performing the } \\
\text { functions of supporting } \\
\text { the activities of the } \\
\text { Ministry of Defense }\end{array}$ & $\begin{array}{l}\text { creation of } \\
\text { enterprises } \\
\text { performing the } \\
\text { functions of } \\
\text { organizing the life } \\
\text { and social security } \\
\text { of the Armed } \\
\text { Forces }\end{array}$ & $\begin{array}{l}\text { - implementation of } \\
\text { individual projects } \\
\text { and designs BBCT } \\
\text { - organization of } \\
\text { production and } \\
\text { service BBCT } \\
\text { - resource supply of } \\
\text { the MIC enterprises }\end{array}$ \\
\hline
\end{tabular}

${ }^{3}$ Compiled by the authors on the basis of Chistov, 2012 


\section{Practical Implementation of the Rearmament Program in Russia and the USA: A Comparative Analysis}

One of the main achievements of the Russian Navy in recent years has been the adoption of the "Caliber" cruise missiles. Their effective use in Syria, including their launching from small missile ships (SMS), was a big shock for the West. However, now, with the dissolution of the Intermediate-Range Nuclear Forces Treaty (here and after - IRNFT), the very existence of NCSs with "Caliber" as part of the Russian Navy should be called into question.

The IRNFT at one time put an end to the development of several classes of weapons in the USA and the USSR - ballistic and ground-based cruise missiles with a range of 500 to 5500 kilometers. The United States eliminated "Pershing-2" ballistic missiles and "Griffon" ground-based cruise missiles - the ground version of the "Tomahawk". The USSR eliminated three types of medium-range ballistic missiles, two types of shorter-range ballistic missiles, and the Griffon counterpart, the RK-55 "Relief" missile system, which was a ground-based version of the S-10 "Garnet" system. The launcher of the "Relief" complex mounted on a high-cross-country automobile chassis was equipped with six missiles.

At the same time, the IRNFT did not cover sea-based cruise missiles. As a result, the United States, which has already begun the mass introduction of "Tomahawk" cruise missiles and Mk41 vertical launch vehicles in its Navy, got the opportunity to deploy such missiles in unlimited numbers on ships and submarines.

Today, the United States possesses thousands of such missiles, which even in nonnuclear combat equipment pose a huge danger to any country, including Russia. Calculations show that the United States can easily and without mobilizing reserves deploy a couple of formations (having both aircraft carriers and missile ships with submarines) at sea, each of which will have approximately a thousand such missiles in readiness for immediate launch, in addition to hundreds of deck-based combat airplanes.

For a long time, the Russian Navy did not attach any importance to getting such shock capabilities. And this despite the fact that the OKB "Novator" (an organization formed on the basis of the developer S-10 "Garnet" and RK-55 "Relief" - SMKB "Novator") was able to maintain the scientific and technical backlog obtained during the creation of the RK "Garnet" , and the navy had a substantial number of carriers of such weapons - submarines of 971 project "Shchuka-B". The Navy would not have required any significant expenses, except for the completion of the development of the non-nuclear Garnet that had begun earlier and the minimal modernization of submarines. But the fleet was not interested in this project in the 90-s. 
It was so uninteresting that in the mid-2000s the first two carriers of the new "Caliber" complex (projects 671RTM and 877), created on the basis of the "Garnet" backlog, were decommissioned. Project 971 "Shchuka-B" was also withdrawn from combat, the issue of upgrading the third generation of submarines was actually thwarted ${ }^{4}$. Non-nuclear variants of the "Garnet" did not find its' niche in the fleet. Development work on the new "Caliber" complex was provided by the Navy with huge underfunding, although there was always interest in the system in the Ministry of Defense itself, but not in the Navy.

However, subsequently there was a chain of events, which were initially unrelated to each other, which nevertheless caused the appearance of long-range cruise missiles in the arsenal of the fleet, albeit in an extremely irrational way.

The first circumstance that changed the situation with cruise missiles was the critical situation with the defense industry enterprises financing, in which export was the salvation of the problem. The response of an individual "Novator" design bureau to this challenge was the emergence of the "Club" missile family - export missiles with a relatively short range, created using the backbone of the non-nuclear "Garnet". The missiles turned out successful both in the shock (against the coast), and in the antiship variants.

An order soon followed - the Indian Navy ordered in Russia a series of Talwar-class frigates of 11356 project, staffed with the "Club" complex missiles in the installation of the vertical launcher for eight missiles. The first of these ships was laid down at the Baltic Shipyard in March 1999. Also, export submarines began to receive the missile system. The installation of the "Club" complex on a 636 Project submarine (and their mass export series) became a "breath of oxygen" for Russian submarine shipbuilding. But they were made for export at that time.

The situation was paradoxical. While foreign buyers systematically armed their ships with Russian cruise missiles, the domestic fleet had nothing of the kind and did not plan to have it. As a result, abnormality of this situation was strictly criticized at a special meeting in Kremlin by the Russian President V.V. Putin in 2006 - with tough conclusions regarding the Navy.

As a result, the Navy rushed to complete the development works and put the "Caliber" on any suitable new ships. The first was the Rocket Ship "Dagestan" completion with the modernization of the previously laid down ship with the deployment of the "Caliber" missile weapons complex on it. The results of the Zelenodolsk Design Bureau forcing the completion of 11661 Project under the "Caliber" missile system became the basis for the deep modernization of the 21630 Project small artillery ship (SAS) into the small missile ship (SMS) of 21631 Project "Buyan-M".

\footnotetext{
${ }^{4}$ Compiled by the authors on the basis of oruzhie.info.
} 
In May 2010, a tender was held to determine the contractor for the construction of a series of new small missile ship (SMS). The tender was won by the Zelenodolsk shipyard ${ }^{5}$. Already in August 2010, the first specialized carrier of such missiles was launched - it was the "Grad Sviyazhsk" ship. The combat use of these ships in 2015 was successful and shocked observers in the West. But behind this success was the fact that the entire missile salvo of the Caspian flotilla was and remains many times less than that of any modern US-destroyer.

\section{Crucial Strategic Difference Between the Russian and the American Attitude Towards NAVY Tasks}

The "land logic" laid down in the design of this ship is striking. It is actually a floating rocket battery. "Buyan-M" has no opportunity to detect either a submarine or detect the launch of its torpedoes. The project has inherent problems with attacks on surface targets - own target designation system lacks. The ship has extremely weak air defense, cannot boast of either speed or seaworthiness. The interbase transition of such ships to the Baltic Fleet was very difficult: both for the crew and with significant restrictions on the use of the "Caliber" missile system.

Having received these "floating batteries", the Navy, in view of the critical situation with the naval staff, began to use them as full-fledged ships. For example, SMSs of the "Buyan-M" project are constantly located in the Mediterranean Sea (actually mostly located in the port of Tartus). It is precisely there that these ships do not have significant combat value, solving the problem of actually displaying the flag. In the Mediterranean, such a ship is just a target.

The key problem of the chosen path for the "calibration" of the Navy is its high cost combined with a small number of deployed cruise missiles. At the same time, the April 14, 2018 strike on Syria by the U.S. Navy and its allies showed that modern missiles can effectively get off - and the question of creating powerful (effective) missile salvos is very acute. Unfortunately even the entire Black Sea Fleet salvo of the "Caliber" missile complex is smaller than the missile salvo of one modernized destroyer "Spruence" of the US Navy (all have already been decommissioned, there can be no discussion of comparison with the newer ships of Arly Burke-class).

In the framework of "naval thinking" (as opposed to "land"), cruise missiles must be placed on multi-functional ships capable of "moving out" the launch line into the far sea zone and from there reaching targets in places that the enemy considers safe. On ships capable of independently using special launchers for launching anti-ship missiles on enemy surface ships, and for launching anti-submarine missiles on detected submarines. Russia has built and keeps building such ships-frigates of 22350 project and corvettes of 20385 project. Cruise missiles and the latest series of "Varshavyanka" 636 submarines project can be used. SMSs of 21631 project are

${ }^{5}$ Compiled by the authors on the basis of Russian Military Industries List, 2018. 
created in a completely different paradigm - it is simply a substitute for the once banned by IRNFT ground launchers.

From the economic point of view it is a very expensive substitution. In 2016-2017 prices one such ship costs nine billion rubles - almost half of the corvette 20385 . Only the corvette has incomparably greater combat capabilities and can operate independently. Foreign diesel engines are partly to blame for such a price - SMSs are designed for four German MTU engines. Later, these engines came under sanctions, and now Chinese diesel engines manufactured by Henan Diesel Engine Industry Ltd., which required a long and serious revision, are now being put on all ships under construction.

Unlike the USA, Russia has unfortunately missed the opportunity to quickly modernize the ships of the military due to the deployment of the "Caliber"-type missiles in inclined launchers (for example, the modified standard projectile launchers KT-100 project 1155). Instead, the ships either remained "bare" or went under an extremely costly upgrade with the installation of a vertical launch launcher (as it was implemented on the Big Antisubmarine Ship "Shaposhnikov").

Another option for the quick and effective Navy "calibration" was the modernization of 1234 Project SMSs by equipping them with the "Caliber" complex in the already mentioned inclined launchers. Taking into account the experience in creating the 1234.7 missile launcher with twelve "Onyx" anti-ship missiles, it should be assumed that up to sixteen "Caliber" missiles can be deployed, which, combined with the air defense system and artillery, makes such missile defense systems very powerful carriers (more than twice the size of the project 21631 missile systems). They are also able to attack surface targets. But instead of that, 1234 SMSs were rearmed of the "Uran" Missile Complex, which seriously limits their combat capabilities.

Having accumulated negative experience with the "Buyan-M", the Navy initiated the creation of a series of other small missile ships - 22800 "Karakurt" project. New ships were a reaction to the problems of the old ones, without assessing how justified a specialized ship was for the fleet at all. "Karakurt" was provided with greater speed and better seaworthiness, they received a target designation complex, with the installation of the "Pantsir-M" complex, air defense was sharply strengthened. The ship was created in the shortest possible time: the lead "Karakurt" was built faster than even the lead small missile ship of 1234 Project in the USSR!

After the start of the construction of "Karakurt", it turned out that there was no enterprise capable of building the engines for them - the main producer of domestic high-speed marine diesel engines, the shipyard Zvezda from St. Petersburg, was unable to produce the required amount of diesel engines. Even several built ships of this class will stand at the outbuilding walls for several years, waiting for their main power plants. Not until question of their "hearts" (Main Power Plants, MPP) reached 
the level of the Supreme Commander-in-Chief again, were the necessary decisions made to accelerate the production of their diesel engines ${ }^{6}$.

But finally the fate of floating batteries was put "in question" by none other than Donald Trump. The US withdrawal from the IRNFT completely deprives the missile floating batteries of meaning - the same missile, but with a ground launch, can now be placed on a ground launcher. And it is much more profitable. The double-battery division of operational-tactical missile system Iskander costs about six billion rubles and provides the same eight-missile salvo. SMSs cost nine billion in 2017. But SMSs, firing rockets, must return to the base, which still needs to be protected from air strikes. Ground launcher is recharged in place, with the help of transport-loading machine.

Thus, in fact, for six billion Russia receives not eight, but 16 missiles in a salvo in a short time. By adding extra missile ammunition, you can increase this amount even more. And if we return to the standard Relief launcher (on the same Minsk MZKT chassis), we get six missiles in the installation, twelve in the battery and twenty-four in the division, plus reserve of transport-loading machine. The price is almost the same as for one SMS, which has only eight missiles.

And if you scale the costs ten times, then instead of eighty cruise missiles in a salvo of ten RTOs, you can get up to two hundred and forty for the same money if you use the "Relief" complex launcher. And it is possible quickly to design a launcher like the old soviet "Molodetz", indistinguishable from the usual civilian road train neither from the satellite, nor from the reflected radar signal, nor into night optics from several kilometers.

Such machines will also provide more salvo than a multiple launch vehicle and will also be cheaper. In addition, ground-based launchers can be dispersed, masked in forests, and shelter underground. Yes, and to protect them from air strikes is much easier, because they can stand in the rear, while SMSs are always at sea - at the forefront.

Russia certainly needs a powerful fleet. Sea-based cruise missiles are also needed, and it is quite possible and necessary to arm full-fledged warships and submarines with them. But the continuation of the construction of small missile ships in the existing form is the throwing of state money to the wind, which after the abolition of the IRNFT makes absolutely no sense.

\section{Conclusion}

What should be done in the practical sense? First of all - to stop the construction of this class of ships. Second - to return to the inclined launchers (along with vertical

\footnotetext{
${ }^{6}$ Compiled by the authors on the basis of Russian State Armament Program, 2015.
} 
ones on new ships) for mass modernization of large naval warships. This does not negate the fact that vertical launch installations can also be installed on modernized ships, in case it is impossible to be done in any other way. Third, to modernize all submarines with a significant remaining service life for the use of "Caliber" missile complex. Fourth, to ensure the use of the complex on new types of warships, which will be built for the Navy in the future (corvettes, frigates). It's time to think about more rational ways of spending the money allocated for the fleet. While implementing the greatest rearmament in its history, Russian Federation cannot allow building disused floating rocket batteries.

In the sphere of PPP the measures seem to be the following. Obviously, it is advisable to combine the positive aspects of the two approaches - competition inherent in private business, and long-term public administration. Moreover, the state itself must constantly take care of creating an effective competitive environment as a factor in dynamic development. Therefore, the organization of effective interaction between the Russian defense industry and private business is currently an important state task. Its relevance is due not only to the need to create a well-equipped Armed Forces that fully meets modern global challenges, but also to the need to restore the rhythmic and dynamic functioning of one of the most important sectors of the Russian economy, which, through the development and subsequent replication of new promising technologies, can become the driver of the mechanical engineering development. The development of the defense industry will give impetus to engineering, the chemical industry, and information technologies.

Thus, the state's financial and economic policy in the field of defense and modernization of the domestic defense industry has all chances to become the locomotiveof the country's industrial,scientific and technological development as a wholein themedium term, provided that the priorities that are correctly chosen are maintained (Martynenko and Parkhitko, 2018).

So far, private business has been reluctant to become a partner in large companies in the production of military hardware, since, along with the low profitability of the defense industry, until recently, there was a practice where the Ministry of Defense made adjustments to the already approved state order. Therefore, it was extremely difficult for little profitability enterprises, not having guaranteed long-term orders, to be interested in roduction cooperation.

The development of cooperation between business and the MIC at the state level should go along the path of creating conditions for public-private partnerships (PPPs) - a set of organizational, legal, financial and economic relations and joint actions of the state and private business aimed at achieving the goals of the state economic policy in order to address socially significant tasks on mutually beneficial conditions. This form of economic and business development, such as PPPs, has been widely developed abroad. All the leading manufacturers of military equipment 
in the USA are non-state, however, the participation and influence of the state in their activities is quite large.

\section{References:}

971“Shchuka-B” Project. 2018. Nuclear submarines. Available online: http://oruzhie.info/podvodnye-lodki/477-proekt-971-shchuka-b

Bezborodov, A., Pavlenko, O. 2014. Military-Technical Aspects of the National Security of the Russian Federation. RSUH/RGGU Bulletin, 18(140), 133-155.

Caliber-NK missile system. 2015. Main tactical and technical characteristics and history of creation. Available online: https://militaryarms.ru/boepripasy/rakety/komplekskalibr-nk/

Chistov, I.V. 2012. Background and directons for the public-private pertnership development in the Russian military-industrial complex. Threats and Security, 48(189), 35-44.

Gerasimov, V. 2013. The future is being laid today. Military-industrial courier, 10.

Glybin, M.Yu. 2014. Public-Private Partnership in the Military-Industrial Complex. Vestnik RUDN, series State and Municipal Administration, 3, 100-110.

Martynenko, El.V., Parkhitko, N.P. 2018. Implementation of the Russian State Armaments Program 2011-2020: Economic and Financial Analysis. European Research Studies Journal, S2(21), 506-517.

Russian Military Industries List. 2018. Spisok predpriyatiy OPK. Available online: https://kcst.bmstu.ru/rating/2-uncategorised/985-spisok-predpriyatij-opk

Russian State Armament Program. 2015. Implementation Problems and Optomization Potential. Analytical Report. Available online: http://cast.ru/files/Report_CAST.pdf

Samarin, I.V. 2014. Public-private partnership in the military-industrial complex: Prospects and Challenges. Humanities, social-economic and social sciences, 5.

Shishkov, B.E. 2015. Mechanisms of public-private partnership in the military-industrial complex. Intellectual property. Industrial property, 2, 4-13.

SSC-X-4. 2018. The Slingshot Project. Available online: http://militaryrussia.ru/blog/topic601.html

Varnavsky, V.G. 2010. Public-Private Partnership. Theory and practice. Moscow, SU-HSE.

Varshavyanka. 2017. Diesel submarine Varshavyanka of 636 and 877 projects: design, armament, tactical and technical characteristics. Available online: https://militaryarms.ru/voennaya-texnika/podvodnye-lodki/varshavyanka/

Vorushilin, L.V. 2014. Public-private Partnership in the Defense Industry Complex: Analysis of Specificity and Prospects of Development. Management Conculting, 3.

VZ. 2019. The United States withdraws from the game the entire class of Russian warships. Available online: https://vz.ru/society/2019/10/8/1001669.html 